\title{
THE SPECTRUM OF NON-CHARACTERISTIC ORAL MANIFESTATIONS IN COVID-19- A SCOPING BRIEF COMMENTARY
}

\author{
Hanna Hüpsch-Marzec ${ }^{1}$, Arkadiusz Dziedzic², Dariusz Skaba ${ }^{1}$, Marta Tanasiewicz ${ }^{2}$
}

Medical University of Silesia in Katowice, Zabrze, Poland

Faculty of Medical Sciences in Zabrze

${ }^{1}$ Department of Periodontal Diseases and Oral Mucosa Diseases

${ }^{2}$ Department of Conservative Dentistry and Endodontics

\begin{abstract}
Virus-induced oral abnormalities, occurring especially in severe COVID-19 cases of hospitalized patients, have various characteristics and clinical features being, either directly or indirectly, related to SARS-CoV-2 infection. Deregulation of the immune system as a result of SARS-CoV-2 infection may lead to the impairment of the normal defense pathway in the SARS-CoV-2 positive patients. This scoping mini-review is aimed to critically appraise the existing evidence concerning the potential link between COVID-19 condition and abnormal manifestations within oral cavity, affecting oral mucosa, salivary glands and sensory elements. COVID-induced oral mucosa manifestations, with various clinical aspects, are likely to occur as coinfections and secondary symptoms, as immune system imbalance is per se a causative factor of secondary manifestations. Oral mucosal lesions related to SARS-CoV-2 infection do not seem to demonstrate gender predilection, with the average reported age around 50 years of age. They include mainly white and erythematous plaques, ulcers, blisters, petechiae. The affected intraoral areas were mainly: tongue, palate, lips, gingiva, and buccal mucosa. The "aggressive" therapies utilized to treat COVID-19, including drug interactions may aggravate or initiate OMLs pathologies. Neglected oral hygiene or partial or complete abandonment of oral hygiene during intensive hospitalization constitutes an independent factor promoting a wide range of oral pathologies. In addition, stress factor indirectly impairs functioning of the immune system. Oral mucosa lesions occurring in COVID-19 cases present with a wide variation of non-characteristic features. These intraoral, soft tissues abnormalities seem to be reversible and transient. A potential impact of severe oral pathologies to systemic health resulting from SARS-CoV-2 infection, along with associated poor oral hygiene should not be ignored, predominantly in seriously ill patients hospitalized in intensive care units. Med Pr. 2021;72(6):685-92
\end{abstract}

Key words: SARS-CoV-2, COVID-19, oral lesions, oral manifestations, oral cavity, salivary glands

Corresponding author: Hanna Hüpsch-Marzec, Medical University of Silesia in Katowice, Faculty of Medical Sciences in Zabrze, Department of Periodontal Diseases and Oral Mucosa Diseases, pl. Traugutta 2, 41-800 Zabrze, Poland, e-mail: hanna.hupsch-marzec@sum.edu.pl

Received: March 25, 2021, accepted: June 28, 2021

\section{INTRODUCTION}

In December 2019, a significant number of patients with pneumonia was reported in Hubei Province in China. The steady increase in the incidence of the disease soon caught the attention of the world. The World Health Organization (WHO) named the new pneumonia coronavirus disease (COVID-19) caused by a new type of coronavirus isolated from the respiratory epithelial cells - severe acute respiratory syndrome coronavirus-2 (SARS-CoV-2). The most important initial symptoms of an already well-described disease include fever, fatigue, dry cough, muscle aches and shortness of breath. Some patients suffer from headache and dizziness, abdominal pain, diarrhoea, nausea and vomiting. Patients who qualified for hospitalization, i.e., those with a severe course of the disease, present on average 30 symptoms associated with COVID-19.

The results of diagnostic laboratory tests show an increase in the level of C-reactive protein (CRP) and leucopenia with lymphopenia in patients with severe form of COVID-19, which clearly indicates a direct systemic impact on defence systems. The disease may lead to progressive respiratory failure due to damage to the alveoli, and death $[1,2]$. Due to the rapid, global spread of COVID-19, and because of the fact that disease with all its varieties is still a serious threat to people all over the world, affecting almost all populations, it is predicted that the prevalence of oral diseases will also increase.

Severe acute respiratory syndrome coronavirus-2 (SARS-CoV-2) is transmitted directly from person to person by airborne droplets in exhaled air, during 


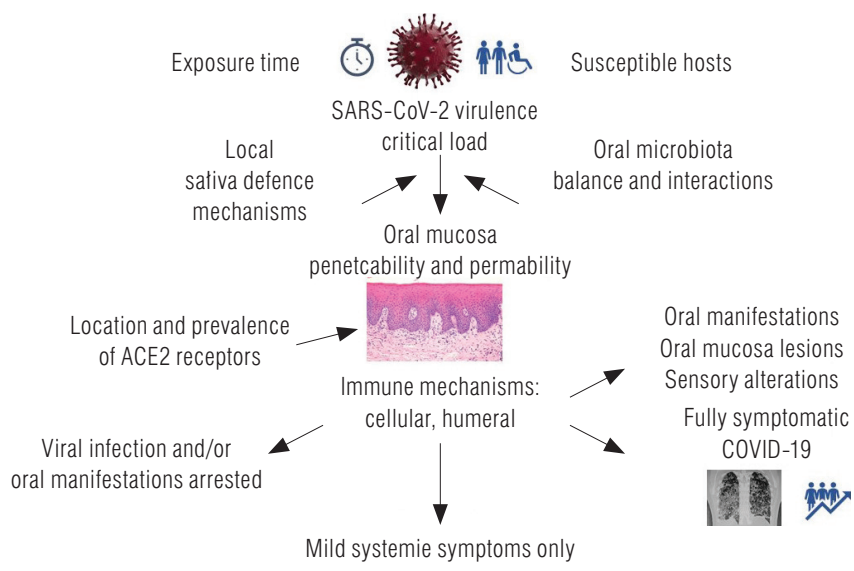

Figure 1. The multi-directional mechanisms of SARS-CoV-2 viral invasion and oral manifestations

coughing and sneezing. New research results reveal that the virus can also be transmitted by the faecal-oral route. Also, a person can possibly be infected indirectly, by touching the surface or an object on which the virus is present, followed by touching of the mouth, nose or eyes. The highest risk of SARS-CoV-2 transmission is associated with the early stage of infection [3-5].

The viral load SARS-CoV-2 virus has been shown to be causally related to the severity of COVID-19 symptoms. A high viral load has been found in the mouth and throat of infected patients, including asymptomatic individuals. During the first 10 days, the patient is usually asymptomatic or oligosymptomatic, but highly contagious. The virus incubation period is 2 to 14 days prior to the onset of symptoms. The median incubation period is 5.1 days. Patients may remain contagious for up to 2 weeks after symptoms have disappeared [6].

The SARS-CoV-2 genome is single-stranded RNA. The shape of the virus is close to spherical, and the sheath with the insets makes it look like a solar corona $[3,7]$. It is made up of 4 structural proteins, the spike (S) protein, the envelope protein, the membrane protein and the nucleocapsid protein. The fusion (S) protein, called the spike protein, is responsible for the interaction of virus particles with the receptor and the connection with the membrane of endocytic vesicles. The protein plays an important role in the penetration of the virus into the host cells. Angiotensin-converting enzyme (ACE2) is the receptor to which SARS-CoV-2 virus particles bind. After SARS-CoV-2 fusion with the ACE2 receptor, the virus enters the host cell by endocytosis [7-10]. The serine transmembrane protease 2 (TMPRSS2) is also involved in this process. The presence of these 2 proteins (ACE2 and TMPRSS2) on the surface of cells determines their susceptibility to virus entry. The proteins are present in large numbers on the epithelial cells of the respiratory tract and the endothelial cells of the pulmonary vessels. They can be found in even greater numbers on the surface of nasopharyngeal cells [10].

The mouth is the "gateway" to many viral infections. A review of studies shows that the key pathway of SARS-CoV-2 infection for COVID-19 may begin in epithelial cells of the salivary gland. The glands showed an increased expression of ACE2, which is significantly higher than in the lungs. The activity of the aforementioned serine protease 2 was also demonstrated in the salivary glands. This is also where the SARS-CoV-2 virus colonizes and multiplies. Therefore, the salivary glands constitute a potential important reservoir of SARS-CoV-2, and this also applies to asymptomatic patients [11-14]. The multi-directional mechanisms of SARS-CoV-2 viral invasion and oral manifestations are presented in Figure 1.

A hypothesis has been formulated that periodontal pockets could be a reservoir for SARS-CoV-2. An association has been shown between periodontitis and a higher risk of increased COVID-19 severity in patients with periodontal disease $[15,16]$. Thus, it is crucial to emphasize that maintaining good oral hygiene in hospitalized patients and severe general condition should be a priority, despite the fact that, intraoral examination can be challenging and medical professionals do not routinely consult patients who develop complications in the oral cavity. Saving lives is the priority. As the oral cavity may play an important role as a potential "portal of entry" of SARS$\mathrm{CoV}-2$ virus transmission and replication, this new virus can be undoubtedly in direct or indirect way, responsible for abnormalities and ailments related to the oral health and oral mucosa integrity in the course of COVID-19. Various non-specific oral lesions are described in the mucosa of infected patients, with the clinical evidence is likely to be underreported and underestimated due to the limited number of available observations.

This scoping mini-review is aimed to critically appraise the existing evidence concerning the potential link between COVID-19 infection and abnormal manifestations within oral cavity, affecting oral mucosa, salivary glands and sensory elements.

\section{METHODS}

A mini scoping, critical appraisal of scientific literature related to oral manifestations of COVID-19 was carried out. Key articles were retrieved mainly from the main electronic databases: PubMed/MEDLINE, Scopus, Web of Science, 
Table 1. Oral manifestations of COVID-19

\begin{tabular}{|c|c|c|}
\hline Reference & $\begin{array}{l}\text { Subjects } \\
\quad[\mathrm{n}]\end{array}$ & Lesion/symptom \\
\hline Amorim dos Santos et al., 2021, Brazil [17] & 8 & $\begin{array}{l}\text { multiple ulcers ( } 4 \text { subjects), nodule ( } 1 \text { subject), severe geographic tongue ( } 1 \text { subject), } \\
\text { fissured tongue ( } 1 \text { subject), pustular enanchema ( } 1 \text { subject), blisters ( } 1 \text { subject), } \\
\text { desquamative gingivitis ( } 1 \text { subject), stomatitis aphthous ( } 1 \text { subject) }\end{array}$ \\
\hline Halboub et al., 2020, Brazil [18] & 25 & $\begin{array}{l}\text { ulcers ( } 7 \text { subjects), vesiculobullous/macular lesions ( } 5 \text { subjects), acute parotitis ( } 5 \text { subjects), } \\
\text { erythema multiform-like lesions ( } 5 \text { subjects), }\end{array}$ \\
\hline Iranmanesh et al., 2020, Iran [19] & 93 & $\begin{array}{l}\text { sites of involvement tongue }(38 \%) \text {, labial mucosa }(26 \%) \text {, palate }(22 \%) \text {, gingiva }(8 \%) \text {, } \\
\text { buccal mucosa }(5 \%) \text {, oropharynx }(4 \%) \text {, tosils }(1 \%) \\
\text { Symptomatic patients - } 68 \%\end{array}$ \\
\hline Nuno-Gonzales et al., 2020, Spain [20] & 666 & $\begin{array}{l}\text { oral findings }-25.7 \% \text { patients } \\
\text { papillitis }(11.5 \%) \text {, aphthous stomatitis }(6.9 \%) \text {, glossitis with lateral indentations }(6.6 \%) \text {, } \\
\text { glossitis with patchy depapillation }(3.9 \%) \text {, mucositis }(3.9 \%) \text {, burning sensations }(5.3 \%)\end{array}$ \\
\hline Sinjari et al., 2020, Italy [31] & 20 & $\begin{array}{l}\text { xerostomia (30\%), dysgeusia (25\%), burning sensation }(15 \%) \text {, } \\
\text { difficulty in swallowing }(20 \%)\end{array}$ \\
\hline Brandão et al., 2021, Brazil [24] & 8 & $\begin{array}{l}\text { aphthous-like ( } 8 \text { subjects), necrosis ( } 4 \text { subjects), hemorrhagic ulcerations ( } 1 \text { subject), } \\
\text { dysgusia ( } 6 \text { subjects), anosmia ( } 2 \text { subjects) }\end{array}$ \\
\hline Frani et al., 2020, Italy [29] & 50 & xerostomia (32\%), gustatory dysfunction (75\%) \\
\hline Chen et al., 2020, China [12] & 108 & dry mouth (46.3\%), hypogeusia $(47.2 \%)$ \\
\hline Lechien et al., 2020, France [35] & 2013 & loss of smell (875 subjects), taste dysfunction (56\%) \\
\hline
\end{tabular}

Google Scholar. In all databases, the following search strategy and key words were used, along with MeSH operators: SARS-CoV-2, COVID-19, oral lesions, oral manifestations, oral cavity, salivary glands. Only full-text, peer-reviewed, in English publications were taken into consideration. Most of the included publications were published in 2020, a small fraction in 2021. Studies with unconfirmed or doubtful COVID-19 reports were excluded.

\section{RESULTS}

\section{Scant series of case reports}

\section{and lacking research-based evidence}

Most of the publications linking COVID-19 with oral mucosa lesions (OMLs) are single case reports, with lacking reliable observational studies and meta-analyses (Table 1). One of the first, brief mini-review included 8 publications demonstrating the diversity of manifestations of oral lesions in SARS-CoV-2 positive patients [17]. The authors of a subsequent review with systematic approach described 25 case reports, however some of them were duplicated [18]. It is difficult to determine which lesions were related directly to SARS-CoV-2, and not a consequence of secondary infections, due to immunological disorders or systemic therapy. Some OMLs, such as geographic and wrinkled tongue, may have occurred before the infection, but were asymptomatic, so they were ignored by the patient. Coronavirus disease 2019 (COVID-19) positive state may induce or exacerbate the existing conditions.

In most cases, single or multiple painful ulcerative lesions were described, occasionally well-defined and surrounded by an inflamed limbus, and in 1 case - aphthous stomatitis [17]. Patients also developed small blisters and exfoliative gingivitis accompanied by pain. Persons diagnosed with COVID-19 presented an eruption of pimples with petechiae on a diffuse, erythematous ground, as well as white plaques located on the dorsal surface of the tongue, features of exacerbated geographic tongue, and thick, sticky saliva [18]. Other studies reported a rash on the skin of the face, enlarged submandibular and cervical lymph nodes and intraoral ulcerations were described on the dorsal surface of the tongue, and in another case, herpetic gingivostomatitis lesions [17-20]. Nuno-Ganzales et al. examined symptomatic patients with a mild to moderate form of the disease: oral problems occurred in $25.7 \%$ of the subjects [20].

\section{Spectrum of non-characteristic intraoral signs and symptoms}

In COVID-19 positive persons, the ulcerative lesions usually occur among other pathologies, with the most frequent location on the tongue, which is swollen and painful [17]. Some reports emphasize the presence 
of white and red spots, especially on the dorsal surface of the tongue, resembling a geographical tongue. These features are informally referred to as "covid tongue." The lesions usually persist in the oral cavity for a few days and then disappear as the intensity of other COVID-related symptoms diminishes [21,22]. It is suggested that one of the mechanisms for the formation of mouth ulcers is chronic vasculitis caused by the excessive accumulation of angiotensin II in vascular cells, with the resulting spasm and an increase in vascular permeability promoting the formation of ulceration [23].

Compared to other OMLs, ulcerative lesions are relatively common, although non-characteristic manifestation of COVID-19 [22]. Brandao et al. reported several cases of COVID-19 infection with necrotic mouth ulcers and aphthous lesions developed early in the course of the disease after dysgeusia, which included the tongue, lips, palate and oropharynx. Other researchers have also observed ulcers located on the mucosa of the cheeks. In 1 case, mouth ulceration was the first symptom of COVID-19 [22,24].

Vesicular and vesical lesions were reasonably common, and usually accompanied by a rash on the skin. They differed in size and location, as well as in terms of the ground and included oedema, diffuse erythematous lesions, ecchymosis and in 1 case - the mucosa with the symptoms of erythema multiforme [25]. One of the papers described pigmentation lesions [25-27] (Table 1).

\section{Does SARS-CoV-2 have neurotropic impact on salivary glands function?}

The high SARS-CoV-2 titres in the salivary glands and salivary gland dysfunction were observed in the late stage of COVID-19 [11,12,28-30]. As identified, SARSCoV-2 can cause acute, bilateral or unilateral salivary gland inflammation (sialadenitis) with typical inflammatory features, such as swelling, pain, lymphadenopathy of the surrounding lymph nodes, and secretion disorders [12-14]. The lesions are usually observed in pairs of large glands, but there are also reports of a dysfunction of small salivary glands. In several cases, sialadenitis was the first symptom of SARS-CoV-2 infection followed by the elevated body temperature, muscle pain, impaired sense of smell and the loss of taste [28]. After excluding the presence of antibodies against cytomegalovirus and paramyxovirus, COVID-19-related sialadenitis was diagnosed based on the results of ultrasound and serological examinations [28].

\section{A potential secondary effect - xerostomia}

COVID-19 positive patients burdened with sialadenitis often complain of a feeling of dry mouth. Xerostomia has also been reported in asymptomatic cases without signs of inflammation of the salivary glands. However, there is no information whether xerostomia condition results from reduced salivation, or the dry mouth symptom is accompanied by normal salivation. It was speculated that this condition can be caused by the interaction of SARS-CoV-2 with ACE2 receptors of the salivary glands and its further consequences, either, in other cases, it presents as drugs-induced xerostomia during the treatment of COVID-19 or dehydration. Italian studies showed that in a group of 50 patients with SARS-CoV-2 infection, 16 people (32\%) complained of xerostomia in addition to other symptoms. Similarly, this observation was consistent in another study and accounted for $30 \%$ of hospitalized patients [29-31].

It has been elucidated that ACE2 receptors, which are necessary for the entry of the virus, occur in significant amounts not only in the salivary glands, but also in various areas of the oral mucosa $[17,32]$. A particularly large number of receptors have been identified in the mucosa of the tongue, and slightly less in the mucosa of the cheeks and gums. The results of some studies confirmed that the oral cavity, like the nasal cavity, can be considered not only the "gateway" of infection, but probably the most important area of replication and further transmission of the virus. The receptor location map may also be connected with the places of the most common oral pathology in the course of COVID-19 [32].

\section{The most prevalent sensory symptoms}

Patients who contracted SARS-CoV-2 complain of a variety of clinical oral symptoms. The most commonly described ailment is a complete loss of taste or different taste disorders [33]. The impairment of taste can be caused by a previous upper respiratory tract infection. Although chemosensory disorders are commonly mentioned in flu-like illnesses, they have not been reported in previous SARS and MERS virus outbreaks. These symptoms were reported commonly, together with smell/sensory alteration. In a group of $>10000 \mathrm{pa}-$ tients, at least 1 type of dysgeusia was reported in as many as $45 \%$ of the respondents. Among the people affected by the disorder, $24 \%$ presented features of ageusia, 35\% hypogeusia and 38\% dysgeusia (parageusia). This may be related to a higher ACE2 expression in 
the tongue epithelial cells or to other mechanisms associated with neurotropic affinity and/or neural effects. Sensory disorders occur especially in patients with a mild and moderate form of the disease and are reversible, although the symptoms may persist for a long time while the prevalence depends on country or ethnicity, age, gender, disease severity and other factors not yet explained [2,34-37].

\section{Discrepancy of lesions' location, duration and primary symptoms}

Lesions within the oral mucosa were usually found on the dorsal surface of the tongue (38\%), quite often on the mucosa of the lips (26\%) and the palate $(22 \%)$, less frequently on the gingiva $(8 \%)$, on the mucosa of the cheeks (5\%), in the oropharynx (4\%), and on the tonsils (1\%). Oral mucosa lesions located in the oral mucosa may persist for 3-21 days and then disappear along with systemic symptoms [17].

The vast majority of the patients (68\%) reported pain accompanying the lesions in the mucous membranes, especially those located on the tongue. Some of the respondents complained of burning sensations, others of itching or mouth dryness. Asymptomatic patients constituted $32 \%$ of the study group [19]. Sinjari et al. surveyed 20 patients hospitalized due to SARS-CoV-2. Overall $25 \%$ of them complained of taste disturbances, $15 \%$ suffered from burning in the mouth and 20\% reported difficulties in swallowing [19,31].

Gherlone et al. [38] found, that salivary gland ectasia was common in hospitalized patients. Oral manifestations were detected in $83.9 \%$ while salivary gland ectasia in $43 \%$ of COVID-19 survivors. Salivary gland ectasia reflected the hyperinflammatory response to SARS-CoV-2, as demonstrated by the significant relationship with CRP [38].

\section{Complex, indirect association \\ between oral health and COVID-19}

Oral abnormalities in patients hospitalized for COVID-19 have various origin being, either directly or indirectly, related to SARS-CoV-2 infection. In many patients, several factors probably overlap and interact to enhance the effects by extending the duration of the disease or increasing severity. Poor oral hygiene or complete abandonment of teeth cleaning during intensive hospitalization constitutes an independent, recognised and proven factor promoting a wide range of oral pathologies [39,40]. Deregulation of the immune system as a result of SARS-CoV-2 infection leads to the impairment of the normal defence pathway in the elderly and weakened, with the simultaneous hyperactivity manifested by the socalled "cytokine storms" reported in the severe form of SARS-CoV-2 infection [41]. These systemic reactions to some extent explain the variety of clinical symptoms observed in the COVID-19 positive cohort. As a result of immune system imbalance, impaired immunity is per se a causative factor of secondary infections. Consequently, the latent HSV1 virus may reactivate and other opportunistic infections may develop [42]. Moreover, it has been reported, that new, "aggressive" therapies utilized to treat COVID-19, including multidrug interactions, may aggravate or initiate OMLs pathologies and the resultant ailments [43].

Pathologies within the oral cavity may also derive from mechanical injuries of the mucosa related to intubation and extubation (removing an endotracheal tube from the trachea). After several weeks of lying down, a ventilated patient may develop numerous complications. Usually, a sore throat, hoarseness or difficulty in swallowing that will pass quite quickly. Various injuries to the lips or larynx, damage to the hard tissues of the teeth or even the vocal cords can occur. Other complication are pressure ulcers associated with local, prolonged compression by an endotracheal tube, impaired circulation, and the generally severe condition of the patient $[44,45]$. Studies have shown an almost complete lack of saliva production in intubated and sedated patients [46]. Also, the lack of oral hygiene poses a serious threat to the health and even life of these patients, as bacteria enter the lower part of the respiratory tract mainly by aspiration from the oropharynx or leakage of bacterial secretions around the endotracheal tube cuff. The lungs become infected with pathogenic microorganisms and the cycle of infection and reproduction of pathogenic microorganisms is repeated [45].

In addition, stress factor associated with the uncertainty and living under threat during a pandemic, hospitalization and isolation cause a constant tension that is difficult to avoid. Long-term impact of stress can lead to mental and psychosomatic disorders, also it impairs functioning of the immune system $[45,47]$. In many patients, several factors probably overlap and interact to enhance the final effect by extending the duration of the disease or increasing severity. Lesions in the oral mucosa last for 3-21 days, then they disappear along with systemic symptoms [17]. In the event of finding atypical or 
suspected viral-related oral lesions, a thorough diagnostic approach is recommended, with reliable testing for SARS-CoV-2. Due to the way of SARS-CoV-2 transmission, including saliva reservoirs, the dental practitioners, and oral medicine specialists are exposed to COVID-19 infection in their work environment on daily basis.

\section{CONCLUSIONS}

Compared to the serious consequences of the COVID-19 infection, such as chronic neurological, pulmonary, cardiological problems or death, OMLs are less of a threat to general health, because they seem to be reversible and transient and not progressing continuously. However, a potential impact to systemic health and even life resulting from poor oral hygiene exacerbating OMLs should not be ignored, especially in seriously ill patients hospitalized in intensive care units. The advanced oral infections can spread from localised area via the descending route through secondary infections and the life support procedures such as intubation.

The routine, periodical, oral medicine and specialist consultations will allow effective patient management, early diagnosis and possibly preventing from the number of complications. In fact, a vast majority of COVID-19 related oral lesions are not characteristic and they clinical features are insufficient to make the final diagnosis. Although, similar pathological changes may occur in the course of other respiratory track viral infection such as influenza, parainfluenza, especially in immunocompromised patients, the time of the pandemic prompts clinicians the taking of a more cautious approach.

New variants of the SARS-CoV-2 virus are becoming apparent, and their infectious rate is inevitably increasing. Different occupational groups of dental practitioners, including oral medicine specialists [48] are permanently exposed to viral infection due to direct contact with the patient's respiratory path, long exposure time during procedures and the specific nature of certain treatment requiring aerosol generation. A recently launched research project as multicentre collaboration in Europe aims to assess the prevalence of oral lesions and risk factors in healthcare staff following COVID-19 vaccination [49]. The early recognition of suspected of the SARS-CoV-2 infection in people presenting with OMLs with the absence of systemic symptoms could provide a 'safety net' for the dentist, patient's relatives and workmates.

\section{REFERENCES}

1. Zhou P, Yang XL, Wang GX, Hu B, Zhang L, Zhang W, et al. A pneumonia outbreak associated with a new coronavirus of probable bat origin. Nature. 2020;579(7798):270-273. https://doi.org/10.1038/s41586-020-2012-7.

2. Zhu J, Ji P, Pang J, Zhong Z, Li H, He C, et al. Clinical characteristics of 3062 COVID-19 patients: A meta-analysis. J Med Virol. 2020;92(10):1902-1914. https://doi. org/10.1002/jmv.25884.

3. Lu R, Zhao X, Li J, Niu P, Yang B, Wu H, et al. Genomic characterisation and epidemiology of 2019 novel coronavirus: Implications for virus origins and receptor binding. Lancet Lond. Engl. 2020;395:565-574. https://doi.org/10. 1016/s0140-6736(20)30251-8.

4. Xiao F, Tang M, Zheng X, Liu Y, Li X, Shan H. Evidence for gastrointestinal infection of SARS-CoV-2. Gastroenterology. 2020;158:1831-1833. https://doi.org/ 10.1053\%2Fj.gastro.2020.02.055.

5. To KK, Tsang OT, Yip CC, Chan KH, Wu TC, Chan JM, et al. Consistent Detection of 2019 Novel Coronavirus in Saliva. Clin. Infect Dis Off Publ Infect Dis Soc Am. 2020;71:841-843. https://doi.org/10.1093/cid/ciaa149.

6. Międzynarodowa Federacja Farmaceutyczna: COVID-19: Informacje kliniczne i wytyczne dotyczące leczenia, 26.03.2020, https://www.nia.org.pl/wp-content/uploads/2020/04/FIPPrzewodnik-COVID-19-PL-002.pdf (18.05.2020). Polish.

7. van der Hoek L, Pyrć K, Berkhout B. Human coronavirus NL63, a new respiratory virus. FEMS Microbiol Rev. 2006;(30):760-773. https://doi.org/10.1111/j.1574-6976. 2006.00032.x.

8. Li F. Structure, Function, and Evolution of Coronavirus Spike Proteins. Annu Rev Virol. 2016;3:237-261. https:// doi.org/10.1146/annurev-virology-110615-042301.

9. Nowakowska E, Michalak S. COVID-19 Choroba wywołana zakażeniem wirusem SARS-CoV-2 globalnym zagrożeniem dla zdrowia publicznego. Post Mikrob. 2020; 59(3):227-236. Polish.

10. Liu S, Xiao G, Chen Y, He Y, Niu J, Escalante CR, et al. Interaction between heptad repeat 1 and 2 regions in spike protein of SARS-associated coronavirus: implications for virus fusogenic mechanism and identification of fusion inhibitors. Lancet. 2004;363:938-947. https://doi. org/10.1016/s0140-6736(04)15788-7.

11. Liu L, Wei Q, Alvarez X, Wang H, Du Y, Zhu H, et al. Epithelial cells lining salivary gland ducts are early target cells of severe acute respiratory syndrome coronavirus infection in the upper respiratory tracts of Rhesus Macaques. J Virol. 2011;85:4025-4030. https://doi.org/10.1128/jvi. 02292-10. 
12. Chen L, Zhao J, Peng J, Li X, Deng X, Geng Z, et al. Detection of SARS-CoV-2 in saliva and characterization of oral symptoms in COVID-19 patients. Cell Prolif. 2020;53(12):e12923. https://doi.org/10.1111/cpr.12923.

13. Fisher J, Monette DL, Patel KR, Kelley BP, Kennedy M. COVID-19 associated parotitis. Am J Emerg Med. 2020; 39:254.e1-254.e3. https://doi.org/10.1016/j.ajem.2020. 06.059 .

14. Chern A, Famuyide AO, Moonis G, Lalvani AK. Sialadenitis: A Possible Early Manifestation of COVID-19. Laryngoscope. 2020;130(11):2595-2597. https://doi.org/10. 1002/lary.29083.

15. Badran Z, Gaudin A, Struillou X, Amador G, Soueidan A. Periodontal pockets: A potential reservoir for SARSCoV-2? Med Hypotheses. 2020;143:109907. https://doi. org/10.1016/j.mehy.2020.109907.

16. Herrera D, Serrano J, Roldán S, Sanz M. Is the oral cavity relevant in SARS-CoV-2 pandemic? Clin. Oral Investig. 2020;24:2925-2930. https://doi.org/10.1007/s00784-02003413-2.

17. Amorim dos Santos J, Normando ACG, Carvalho da Silva RL, Acevedo AC, De Luca Canto G, Sugaya N, et al. Oral Manifestations in Patients with COVID-19: A Living Systematic Review. J Dent Res. 2021;100(2):141-154. https://doi.org/10.1177/0022034520957289.

18. Halboub E, Ali Al-Mawer S, Alanazi RH, Qaid NM, Abdulrab S. Orofacial manifestations of COVID-19: a brief review of the published literature. Braz Oral Res. 2020;34:e124. https://doi.org/10.1590/1807-3107bor-2020. vol34.0124.

19. Iranmanesh B, Khalili M, Amiri R, Zartab H, Aflatoonian M. Oral manifestations of COVID-19 disease: a review article. Dermatologic Therapy. 2020; e14578. https://doi.org/10.1111\%2Fdth.14578.

20. Nuno-Gonzales A, Martin-Carrillo P, Magaletsky K, Rios M, Manas H, Argitas J, et al. Prevalence of mucocutaneous manifestations in 666 patients with COVID-19 in a field hospital in Spain: oral and palmoplantar findings. Br J Dermatol. 2020;184(1):184-185. https://doi.org/ 10.1111/bjd.19564.

21. Riad A, Kassem I, Hockova B, Badrah M, Klugar M. Tongue ulcers associated with Sars-CoV-2 infection: A case series. Oral Dis. 2020;00:1-3. https://doi.org/10. 1111/odi.13635

22. Chaux-Badard AG, Deneuve S, Desouther A. Oral manifestations of COVID-19 as an inaugural symptom? J Oral Med Oral Surg. 2020;26(2):18. https://doi.org/10.1051/ $\mathrm{mbcb} / 2020011$.

23. Singh G, Priya H, Mishra D, Kumar H, Monga N, Kumari K. Oral manifestations and dental practice rec- ommendations during COVID-19 pandemic. J Family Med Prim Care. 2021;10:102-9. https://doi.org/10.4103/ jfmpc.jfmpc_1605_20.

24. Brandao TB, Gueiros LA, Melo TS, Prado-Ribeiro AC, Nesrallah ACFA, Prado GVB, et al. Oral lesions in patients with SARS-CoV2 infection: could the oral cavity be a target organ? Oral Surg Oral Med Oral Pathol Oral Radiol. 2021;131:e45-51.

25. Martín Carreras-Presas C, Amaro Sánchez J, LópezSánchez AF, Salas J, Somacarrera Perez ML. Oral vesiculobullous lesions associated with SARS-CoV-2 infection. Oral Dis. 2020;5:10.1111/odi.13382. https://doi.org/10. 1111/odi.13382.

26. Marzano AV, Cassano N, Genovese G, Moltrasio C, Vena GA. Cutaneous manifestations in patients with COVID-19: a preliminary review of an emerging issue. Br J Dermatol. 2020;183(3):431-442. https://doi.org/10.1111/bjd.19264.

27. Corchuelo J, Ulloa FC. Oral manifestations in a patient with a history of asymptomatic COVID-19: Case report. Int J Infect Dis. 2020;100:154-157. https://doi.org/10. 1016/j.ijid.2020.08.071.

28. Capaccio P, Pignataro L, Corbellino M, PopescuDutruit S, Torretta S. Acute parotitis: a possible precocious clinical manifestation of SARS-CoV-2 infection? Otolaryngol Head Neck Surg. 2020;163(1):182-183. https://doi.org/10.1177/0194599820926992.

29. Freni F, Meduri A, Gazia F, Nicastro V, Galletti C, Aragona P. Symptomatology in head and neck district in coronavirus disease (COVID19): A possible neuroinvasive action of SARS-CoV-2. Am J Otolaryngol. 2020;41:102612. https://doi.org/10.1016\%2Fj.amjoto.2020.102612.

30. Xu J, Li Y, Gan F, Du Y, Yao Y. Salivary glands: potential reservoirs for COVID-19 asymptomatic infection. J Dent. 2020 Res:22034520918518. https://doi.org/10.1177/002 2034520918518.

31. Sinjari B, D’Ardes D, Santilli M, Rexhepi I, D’Addazio G, Di Carlo P, et al. SARS-CoV-2 and oral manifestation: an observational, human study. J. Clin Med. 2020;9:3218. https://doi.org/10.3390\%2Fjcm9103218.

32. Xu H, Zhong L, Deng J, Peng J, Dan H, Zeng X, et al. High expression of ACE2 receptor of 2019-nCoV on the epithelial cells of oral mucosa. Int J Oral Sci. 2020;12:1-5. https://doi.org/10.1038/s41368-020-0074-x.

33. Hüpsch-Marzec H. Taste disturbances in the course of SARS-CoV-2 based on the current literature. Twój Przegl. Stomatol. 2021;3,4:82-84. Polish.

34. Pellegrini R, Cooper KW, Di Pizio A, Joseph PV, Bhutani $S$, et al. Corona viruses and the chemical senses: past, present, and future. Chem Senses. 2020;45(6):415-422. https://doi.org/10.1093/chemse/bjaa031. 
35. Lechien JR, Chiesa-Estomba CM, Hans S, Barillari M.R, Jouffe L, Saussez S. Loss of smell and taste in 2013 European patients with mild to moderate COVID-19. Ann Int Med. 2020;173:672-675. https://doi.org/10.7326/m20-2428.

36. Finsterer J, Stollberger C. Causes of hypogeusia in SARSCoV2 infected patients. J med Viro. 2020; 92(10): 17931794. https://doi.org/10.1002/jmv.25903.

37. Tsuchiya H. Oral symptoms associated with COVID-19 and their pathogenic mechanisms: a literature review. Dent J. 2021;9:32. https://doi.org/10.3390/dj9030032.

38. Gherlone EF, Polizzi E, Tete G, De Lorenzo R, Magnaghi C, Rovere Querini P, et al. Frequent and persistent salivary gland extasia and oral disease after COVID-19. J Dent Res. 2021;1-8. https://doi.org/10.1177/0022034521997112.

39. Loe H, Theilade E, Jensen SB. Experimental gingivitis in man. J Periodontol. 1965;36(3):177-87. https://doi.org/ 10.1902/jop.1965.36.3.177.

40. Jepsen S, Blanco J, Buchalla W, Carvalho JC, Dietrich T, Dörfer C, et al. Prevention and control of dental caries and periodontal diseases at individual and population level: consensus report of group 3 of joint EFP/ORCA workshop on the boundaries between caries and periodontal diseases. J Clin Periodontol. 2017;44(Suppl 18):S85-93. https://doi.org/10.1111/jcpe.12687.

41. Cao X. COVID-19: immunopathology and its implications for therapy. Nat Rev Immunol. 2020;20:269-270. https://doi.org/10.1038/s41577-020-0308-3.

42. Rawson TM, Moore LSP, Zhu N, Ranganathan N, Skolimowska K, Gilchrist M, et al. Bacterial and Fungal
Coinfection in Individuals With Coronavirus: A Rapid Review To Support COVID-19 Antimicrobial Prescribing. Clin Infect Dis. 2020;71(9):2459-2468. https://doi.org/10. 1093/cid/ciaa530.

43. Dziedzic A, Wojtyczka R. The impact of coronavirus infectious disease 19 (COVID-19) on oral health. Oral Dis. 2020 Apr 18:10.1111/odi.13359.

44. Hockova B, Riad A, Valky J, Sulajova Z, Stebel A, Slavic R, et al. Oral complications of ICU patients with COVID-19: case-series and review of two hundred ten casus. J. Clin. Med. 2021;10(4):581. https://doi.org/10.3390/ jcm 10040581.

45. Mędrzycka-Dąbrowska W, Dąbrowski S, Basiński A. Aktualne zalecenia w pielęgnacji jamy ustnej u pacjentów zaintubowanych i wentylowanych mechanicznie - przegląd piśmiennictwa. Anestezjologia i Ratownictwo 2012; 6:221-230. Polish.

46. Abidia RF. Oral Care in the Intensive Care Unit: A Review. J Contemp Dent Pract. 2007;(8)1:076-082.

47. Mattos dos Santos R. Isolation, social stress, low socioeconomic status and its relationship to immune response in Covid-19 pandemic context. Brain, Behav. Immun.-Health. 2020;7:100103. https://doi.org/10.1016/j.bbih.2020.100103.

48. Dziedzic A, Varoni EM. Challenges of oral medicine specialists at the time of COVID-19 pandemic [published online ahead of print, 2020 Jul 2]. Oral Dis. 2020;10.1111/ odi.13520.

49. Dziedzic A, Tanasiewicz M. Vaccination side effects. Br Dent J. 2021;230(4):184.

This work is available in Open Access model and licensed under a Creative Commons Attribution-NonCommercial 3.0 Poland License - http://creativecommons.org/licenses/by-nc/3.0/pl/deed.en. 